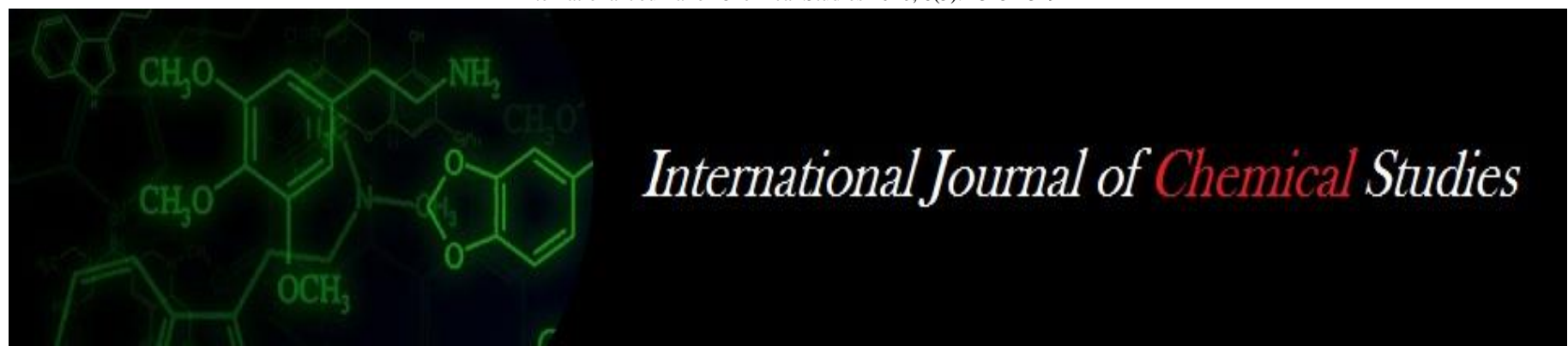

P-ISSN: 2349-8528

E-ISSN: 2321-4902

www.chemijournal.com

IJCS 2020; 8(5): 1345-1349

(C) 2020 IJCS

Received: 15-06-2020

Accepted: 19-07-2020

\section{Shahida Ibrahim}

Shere Kashmir University of

Agricultural Sciences and

Technology, Jammu and

Kashmir, India

Rakesh Kumar Gupta

Shere Kashmir University of

Agricultural Sciences and

Technology, Jammu and

Kashmir, India

Ramandeep Kour

Shere Kashmir University of Agricultural Sciences and

Technology, Jammu and

Kashmir, India
Corresponding Author: Shahida Ibrahim

Shere Kashmir University of Agricultural Sciences and Technology, Jammu and Kashmir, India

\section{Isolation and characterization of a novel paraffin wax and solid wax degrading endosymbiotic bacteria from Citrus mealy bug (Planococcus citri)}

\author{
Shahida Ibrahim, Rakesh Kumar Gupta and Ramandeep Kour
}

DOI: https://doi.org/10.22271/chemi.2020.v8.i5s.10488

\section{Abstract}

Bacterial isolates capable of degrading the paraffin wax and solid wax were isolated from the body of citrus mealy bug. In total nine isolates were isolated but among them only four showed degradation ability by formation of halo on Modified Davis Minimal Agar media and change in colour on Blue spirit agar media. These isolates were identified by 16srRNA and they were Bacillus cereus, Bacillus subtilis, Bacillus licheniformis and Pseudomonas putida. The morphological and biological profile of bacterial strains were also identified. The bacterial species showed reduction in residual amount of liquid paraffin and among them Bacillus subtilis $(3.421 \mathrm{~g}$ ) becomes more efficient. The incubated samples containing strains viz., Bacillus cereus, Bacillus subtilisi, Bacillus licehniformis and Pseudomonas putida showed significant reduction in residual weight of solid wax. The highest reduction was observed by Bacillus cereus $(66.53 \%)$. However, no difference was observed in the residual weight of solid wax in control even after 30 days $(0 \%)$.

Keywords: Isolation, characterization, novel paraffin, Planococcus citri

\section{Introduction}

Over the last few years, Mealybugs (Pseudococcidae: Hemiptera) have assumed serious proportions as the pest of crops and trees as they encrust the leaves, canes and clusters, accentuating crop damage and defoliation. The seriousness of their damage can be gauged from the fact that they attack more than 200 plant species with host records extending to 76 families and over 200 genera with liking for Fabaceae, Malvaceae and Moraceae. They establish and spread more easily than many other insect species owing to the waxy coating on the dorsal surface that shields them from insecticidal and natural mortality factors. Therefore these ensosymbionts can be used to manage the pest population of mealy bug. Similarly the oil industry is currently facing new levels of competition as non-renewable resources are becoming increasingly exhausted. During the crude oil recovery process, paraffin wax is dissolved in the oil to precipitate crystals. These crystals lead to the formation of paraffin wax deposits because of temperature and pressure reduction, and the escape of light alkanes to the atmosphere. Furthermore, the crystals attach to the walls of the oil wells, the casing wall, pump, and other production equipment, which reduces the mobility of oil and blocks the transport in the pipelines. According to reports, more than half of the extractable oil remains underground after the first and second attempts at oil recovery. Therefore, the presence of paraffin wax deposits in oil has become a pressing issue in the oil industry. At present, this problem is solved using thermal fluid treatments, the use of chemicals and solvents, or pigging (scraping). However, most of these procedures currently have certain disadvantages. For example, mechanical scraping causes loss due to significant downtime in production. Chemicals and solvents, aside from being hazardous (Araújo et al., 2010), only partially dissolve or disperse paraffin, which ends up being deposited elsewhere in the tubing (Khalil et al., 1997). Keeping in view all above facts these endosymbionts are used to degrade the wax of mealy bug, waxes in crop residue and paraffin waxes in oil industries. 


\section{Material and Methods \\ Sample collection}

A colony of Planococcus citri exclusively adult female mealybug samples were collected from Sher-e-Kashmir University of Agricultural Sciences and Technology, Main Campus, Chatha, Jammu ( $\left.32^{\circ} 44^{\prime} \mathrm{N} / 74^{\circ} 54^{\prime} \mathrm{E}\right)$. The collected samples were transported to the Biological control laboratory in sealed polythene bags. Live mealy bugs were anaesthetized using $\mathrm{CO}_{2}$ and subsequently killed by freezing on dry ice for one minute while the dead one was freezed.

\section{Rearing of host insect}

A disease free colony of mealybug was reared in the laboratory by collecting from an infested okra field in Chatha Campus, Jammu, Jammu \& Kashmir, India. The life stages were observed under a binocular dissection microscope and coloured photographs by Meyerdirk et al. (1998) ${ }^{[3]}$. The individuals were reared on Indian baby pumpkins, Praecitrullus fistulosus (stocks) (Cucurbitales: Cucurbitaceae). The colony was maintained by releasing one female per pumpkin kept in rearing cages at $37 \pm 2^{\circ} \mathrm{C}, 70 \pm$ $5 \% \mathrm{RH}$, and photoperiod (16:8h) light: dark.

\section{Sterilization of glassware}

A laboratory grade chemicals and solvents were purchased and used in this study. Growth media and the enriched components were obtained from HiMedia. The glasswares were cleaned using chromic acid cleaning solution. The mixture was prepared by dissolving $75 \mathrm{gm}$ of Potassium dichromate in $50 \mathrm{ml}$ of warm water, that was cooled and then $500 \mathrm{ml}$ of sulphuric acid was added to it gently for 24 hours, washed using running tap water followed by distilled water and air dried. Glassware, Media and other materials were autoclaved at $121^{\circ} \mathrm{C}$ at $15 \mathrm{psi} / \mathrm{sq}$. inch for 15 minutes.

\section{Isolation and purification of bacteria}

Isolation and purification of potential endosymbionts associated with mealy bug was carried out using cadavers of adult mealy bug. The collected insect cadavers were immersed in sterile saline solution $(0.8 \%)$ in $250 \mathrm{ml}$ capacity conical flask and were incubated for 30 minutes at $120 \mathrm{rpm}$ on a shaker for vigorous mixing. A sample of each suspension was streaked onto sterile modified Davis Minimal Agar in petriplates and incubated at $\pm 37^{\circ} \mathrm{C}$ for growth of bacteria. The pure culture of bacteria was obtained by Streak plate method. In this method a loopful of bacterial cells was streaked across the agar - solidified surface of a nutrient medium and a diluent gradient was established across the face of the plate. The plates were then incubated at $37^{\circ} \mathrm{C}$ for $48 \mathrm{~h}$ to permit the growth. Isolated colonies so developed in some regions of the plate were picked using sterile loop and were repeatedly subcultured by streak inoculation until single cell colonies were obtained. Pure cultures of the endosymbiont bacteria associated with mealy bug were maintained on Nutrient agar slants at $4{ }^{0} \mathrm{C}$ until further analysis.

\section{Screening}

For screening the presence of wax degrading bacteria, sample of each solution was streaked onto sterile Modified Davis
Minimal Agar incubated at $37^{\circ} \mathrm{C}$ for $48 \mathrm{~h}$. Production of clear haloes with diameter larger than $10 \mathrm{~mm}$ (antibiotic zone scaleCPW279) confirmed the presence of wax degrading bacteria. Further, spot inoculation of bacterial cultures on spirit blue agar medium containing wax instead of tributyrin (Himedia) also confirmed the presence of degrading bacteria. The isolates which made the spirit blue agar media transparent were selected for further studies.

\section{Identification}

The isolates were grown overnight on Luria agar (LA) plates. Genomic DNA was extracted from one colony for each bacterium using phenol-chloroform as described by Sambrook et al. (1989) ${ }^{[7]}$. The extracted genomic DNA was sent to ILRI, Ranchi, Jharkhand, India for identification by $16 \mathrm{~S}$ rRNA technique. The identification of the bacterial isolates was further validated by recording morphological data regarding the form (circular, filamentous, or irregular), elevation (flat, convex, or umbonate), margin, (entire, undulate, erose, or filamentous), and optical features (opaque, translucent, or transparent) of the colonies. Further, cells were observed under a microscope (oil immersion, 100x) for gram reaction and spore production (Gerhardt, 1981). Different biochemical tests viz., Amylase, Catalase, Lipase, Oxidase, Indole, Pigment production, Fluorescence, Prodiginosin, Chitinase etc were also performed using KB002 HiAssortedTM rapid biochemical kit (HiMedia, Mumbai, India). Based on the results, the selected isolates were tentatively identified according to Bergey's manual of systematic bacteriology (Holt, 1994) ${ }^{[14]}$.

\section{Results \\ Isolation and screening}

Isolation from the cadavers of Planococcus citri collected from the field indicated presence of nine bacterial strains. Among them only four isolates showed paraffin wax, chlorpyriphos and polyethylene degrading ability by showing halo formation on Modified davis minimal agar media and chaning colour of Blue sprit agar into transparent for paraffin wax and reduction in quantity of chlorpyriphos and polyethylene (Table 1)

\section{Identification}

The four isolates viz. 1, 3, 6 and 7 were identified by $16 \mathrm{~S}$ rRNA gene sequencing technique and they were found to be Bacillus licheniformis, Pseudomoas putida, Bacillus subtilis and Bacillus cereus respectively (Table 2 ). The morphological characteristics of four degrading bacteria species obtained from Planococcus citri are presented in Table 3.

\section{Qualitative biochemical profile of four degrading bacterial isolates obtained from citrus mealybug, Planococcus citri cadavers}

The results of qualitative biochemical tests of four degrading bacteria obtained from $P$. citri are presented in the Table 4. All the bacterial species were found catalase and lipase positive whereas Pseudomonas putida and Bacillus lichaniformis showed chitinase positive.

Table 1: Liquid paraffin wax and solid wax degrading ability of isolated bacteria

\begin{tabular}{|c|c|c|}
\hline \multirow{2}{*}{ Bacterial Isolate No } & \multicolumn{2}{|c|}{ Liquid Paraffin wax and solid wax } \\
\cline { 2 - 3 } & Halo formation on MDMA* media & Transparent colour on SBA* media \\
\hline 1 & Positive & Positive \\
\hline 2 & Negative & Negative \\
\hline \multicolumn{2}{|c|}{$\sim 1346 \sim$} \\
\hline
\end{tabular}




\begin{tabular}{|c|c|c|}
\hline 3 & Positive & Positive \\
\hline 4 & Negative & Negative \\
\hline 5 & Positive & Negative \\
\hline 6 & Negative & Positive \\
\hline 7 & Positive & Positive \\
\hline 8 & Negative & Negative \\
\hline 9 & Negative & Negative \\
\hline 10 & Negative & \\
\hline
\end{tabular}

*MDMA- Modified Davis Minimal Agar

*SBA- Spirit Blue Agar

Table 2: Insecticide and polyethylene four degrading bacterial isolates identified by $16 \mathrm{~S}$ rRNA gene sequencing

\begin{tabular}{|c|c|}
\hline Bacterial Isolate & Identified isolates scientific name \\
\hline 1 & Bacillus licheniformis \\
\hline 3 & Pseudomonas putida \\
\hline 6 & Bacillus subtilis \\
\hline 7 & Bacillus cereus \\
\hline
\end{tabular}

Table 3: Morphological characteristics of four degrading bacteria isolated from P. citri

\begin{tabular}{|c|c|c|c|c|}
\hline \multirow{2}{*}{ Characteristic } & \multicolumn{4}{|c|}{ Degrading bacterial species } \\
\cline { 2 - 5 } & Bacillus Licheniformis & Pseudomonas putida & Bacillus cereus & Bacillus Subtilis \\
\hline Configuration & Rod & Oval & Irregular & Irregular \\
\hline Margin & Entire & Wavy & Undulated & Undulate \\
\hline Elevation & Umbonate & Umbonate & Raised & Umbonate \\
\hline Surface texture & Mucoid & Mucoid & Dry & Dry \\
\hline Cell shape & Straight rods & Rods & Rods & Rods \\
\hline Cell size & $0.5-1 \mu \mathrm{m}$ & $0.5-1 \mu \mathrm{m}$ & $0.5-1 \mu \mathrm{m}$ & $0.5-1 \mu \mathrm{m}$ \\
\hline Spores & Positive & Negative & Positive & Positive \\
\hline Motility & Positive & Positive & Positive & Positive \\
\hline Pigment & Positive & Positive & Negative & Negative \\
\hline Opacity & Positive & Negative & Positive & Negative \\
\hline
\end{tabular}

Table 4: Biochemical profile of four degrading bacteria isolated from Planococcus citri

\begin{tabular}{|c|c|c|c|c|}
\hline Biochemical test & Bacillus subtilis & Bacillus Cereus & Pseudomonas putida & Bacillus Licheniformis \\
\hline Gram Stain & Positive & Positive & Negative & Positive \\
\hline Amylase & Positive & Positive & Negative & Positive \\
\hline Catalase & Positive & Positive & Positive & Positive \\
\hline Lipase & Positive & Positive & Positive & Positive \\
\hline Oxidase & Positive & Negative & Positive & Negative \\
\hline Indole & Positive & Negative & Positive & Negative \\
\hline Pigment production & Negative & Negative & Positive & Positive \\
\hline Fluorescence & Negative & Negative & Positive & Negative \\
\hline Prodiginosin & Negative & Negative & Negative & Positive \\
\hline Chitinase & Negative & Negative & Positive & Positive \\
\hline
\end{tabular}

\section{Changes in residual weight of Liquid paraffin}

All bacteria showed significant reduction in weight of liquid paraffin $(\mathrm{t}=7.641, \mathrm{df}=14$ and $\mathrm{p}=0.000)$ over control (Plate 11). Among all the treatments, Bacillus subtilis (3.421g) was found to be most efficient followed by Pseudomonas putida (3.471g), Bacillus cereus (3.568g), Bacillus licheniformis (3.576g) and control (4.90 g) (Fig. 1).

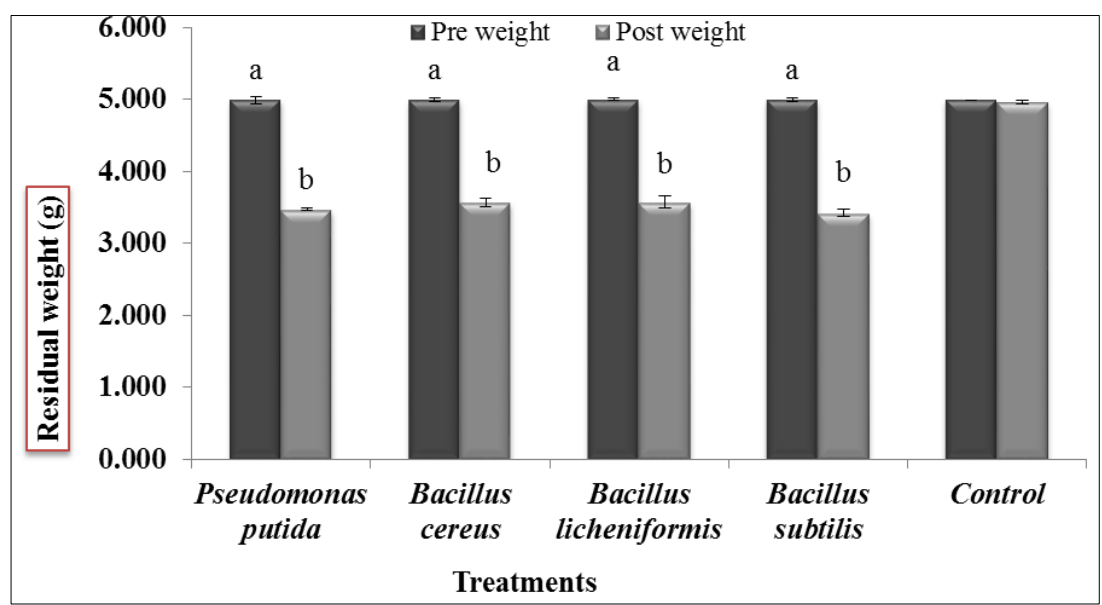

Fig 1: Changes in residual weight of Liquid paraffin within 30 days of incubation time by different bacterial species 


\section{Effect of different bacterial species on residual weight of solid wax}

The incubated samples containing strains viz., Bacillus cereus, Bacillus subtilisi, Bacillus licehniformis and Pseudomonas putida showed significant reduction in residual weight of solid wax $(\mathrm{t}=7.286, \mathrm{df}=14, \mathrm{p}=0.000)$ over control. The highest reduction was observed by Bacillus cereus (66.53\%) followed by Bacillus subtilis (62.20\%), Pseudomonas putida (58.66\%) and Bacillus licheniformis (48.42\%) (Fig.2). However, no difference was observed in the residual weight of solid wax in control even after 30 days $(0 \%)$.

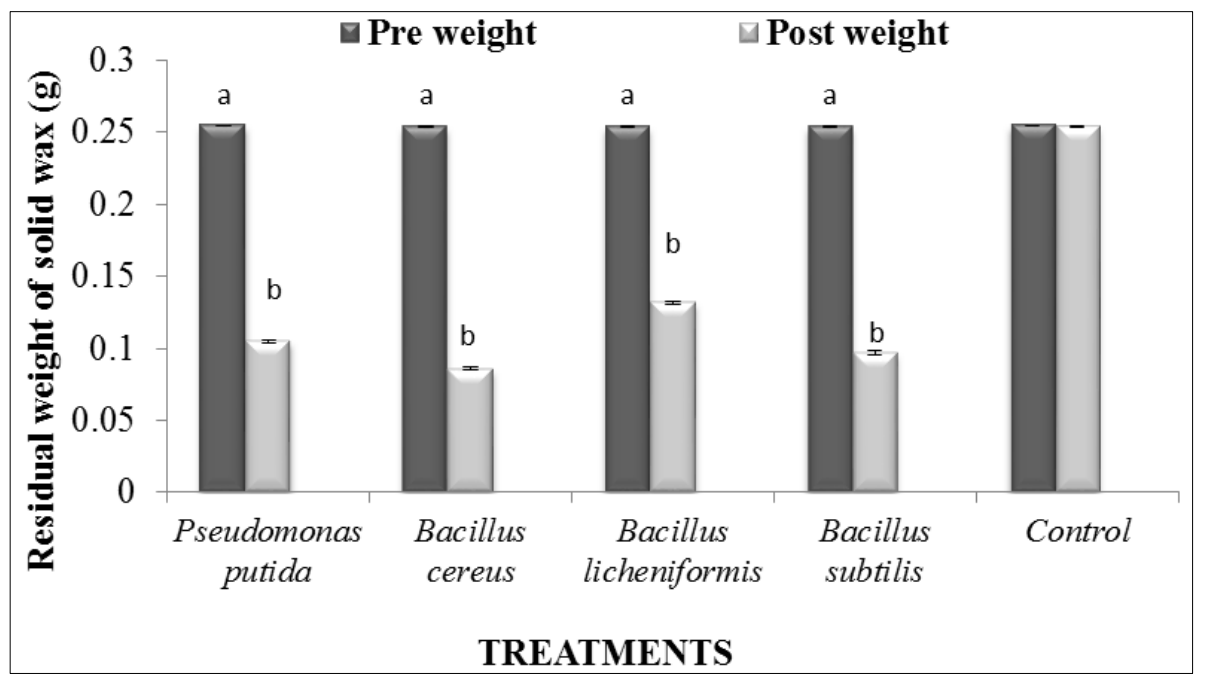

Fig 2: Effect of different bacterial species grown on NA on residual weight of solid wax after 30 days of incubation period

Within bars mean \pm SE bearing similar superscript of small letter do not differ significantly (Student t- test at $p<0.05$ )

\section{Discussion}

The aim of this study was to explore the possibility of using endosymbionts for bioremediation of pesticide, wax and polyethylene. Since, mealy bug is well known to escape the pesticidal treatments due to presence of wax and also known to detoxify the pesticides due to presence of endosymbionts (Sreerag et al. 2014) [11] and are capable of developing resistance to insecticides. Therefore these endosymbionts could be explore in degradation of waxes. Natural Bioremediation has been used by civilizations for the treatment of waste water but its application in agriculture has immense potential to not only reduce the pesticide in the ecosystem but also the agricultural waste, crop residues and polyfilms. The use of microorganisms to remediate/ destroy or to immobilize pollutant from environment is a recent approach that might be considered as excellent process to remove agrochemicals in water, soil and sediments (Demnerova et al., 2005).

\section{Isolation and Identification}

Almost all insects have endosymbionts associated with them, required for their normal growth and development (Munson. et al. 1992). However, the loss of these microorganisms can result in the abnormal development and reduction in the survival of the insect host (Fukatsu and Hosokawa. 2002). Different phytophagous insects are known to be associated with various bacteria species and depending upon the nature of their association, these bacteria can be used in biological control of such insects. Similarly, the body of mealy bug also has some endosymbionts (Bacteria, Viruses) which live inside the body of insect. Isolation of endosymbiotic bacteria have been carried out from mealy bug (Gatehouse et al. 2012, Kantheti et al. 1996, Munson et al. 1992) and other sap sucking insects (Bing et al. 2013) and their role for degradation of organophosphate compounds was explored successfully. However, the present study not only explored their role for degradation of insecticide but also for wax and polyethylene. The isolation from the cadavers of Planococcus citri collected from the field indicated presence of nine endosymbiont bacterial strains. Primary screening of these 9 isolates by Halo formation on Modified Davis Minimal Agar medium and transparent colour on Spirit Blue Agar media in case of paraffin wax resulted in the presence of four isolates with degrading ability of paraffin wax. The identification of these four bacterial isolates was done by 16srRNA sequencing and the identified bacterial isolates were Bacillus subtilis, Bacillus licheniformis, Bacillus subtilis and Pseudomonas putida. The biochemical profile (Amylase, Catalase, Lipase, Oxidase, Indole, Pigment production, Fluorescence, Prodiginosin, Chitinase) of four degrading bacteria isolated from $P$. citri have proven their ability to degrade the wax, chlorpyriphos and polyethylene due to presence of certain enzymes produced by microorganisms. The results of present findings were in line with the study of several researchers who demonstrated hydrocarbons/Polythene/Paraffin degrading capacity of certain bacterial species like Bacillus Yang et al., 2014) ${ }^{[13]}$, S. marcescens, Pseudomonas aeruginosa (Wongsa et al., 2004), Bravibacillus, Achromobacter and Pseudomonas. This may be attributed to presence of certain biosurfactants which utilize wax and their compounds as a sole source of carbon (Singer and Finnertly, 1990; Rocha et al., 1992, Arunkumar et al., 2017) ${ }^{[10,6,1]}$.

\section{Changes in residual weight of Liquid paraffin wax}

The results indicated that all bacterial species significantly reduced the weight of paraffin wax while as Bacillus subtilis was found to be most efficient. Bacillus subtilis ability to degrade paraffin and produce biosurfactant which are major cause of degradation of liquid paraffin. (Querioga et al. 2003) [5]. The present findings were also in line with findings of Mobaiyen et al. (2013) ${ }^{[4]}$. He identified the environmental liquid paraffin decomposer strains. Initially, six strains in duplicate experiment showed paraffin decomposition ability about more than $70 \%$. Then, for molecular recognition of isolates by specific primers of $16 \mathrm{~S}$ rRNA, PCR were done and 
the resulted product of PCR was sequenced and considered strains were isolated. In this study, by sequencing of PCR products, the isolated strains were identified as Streptomyces lavendulae, Bacillus sp. and Streptomyces paracox. The degradation of paraffin wax might also be due to enzyme such as catalase. Paraffins are mainly composed of long-chain alkanes, which are known to be degraded by microbes having catalase enzyme. Pseudomonas putida is among the most extensively studied alkane-degrading bacteria, which catalyzes the hydroxylation of linear and branched aliphatic, alicyclic, and alkylaromatic compounds. This strain is mostly known for its efficient utilization of medium and lengthy carbon chain alkanes from $\mathrm{C} 12$ to $\mathrm{C} 22$ (van Beilen et al., 2001) ${ }^{[12]}$. One more reason is that these bacterial strains decreases the density and viscosity of liquid paraffin. Bacillus subtilis, decreased density and viscosity of paraffin wax more than Bacillus licheniformis, which represents the conversion of long chain alkanes to short-chain alkanes (Sadeghazad and Ghaemi. 2003) ${ }^{[8]}$.

\section{Effect of bacterial species on residual weight of solid wax}

The present investigation lead to finding that a significant reduction in amount of wax was observed whileas Bacillus cereus was the most promising bacterial isolate in reducing the weight of solid wax. Various wax degrading eubacteria genera, Pseudomonas, Alcaligenes, Micrococcus, Nocardia, Corynebacteria, Arthrobacter, Bacillus, Rhodococcus and Proteus capable of decomposing waxy rich residues (Arunkumar et al. 2017) ${ }^{[1]}$. Reason behind degradation of soild wax is production of monoxygenase enzymes by bacterial isolates. Apart from this; wax degrading microorganisms also produce biosurfactants to utilize wax and their compounds. This may be attributed to presence of certain biosurfactants which utilize wax and their compounds as a sole source of carbon (Singer and Finnertly, 1990; Rocha et al., 1992, Arunkumar et al., 2017) ${ }^{[10,6,1]}$. The results of present study are in line with the findings of Sakthipriya et al. (2015) ${ }^{[9]}$ demonstrated biosurfactant producing Pseudomonas aeruginosa and Pseudomonas fluorescens with waxes as sole source of carbon. Microorganism must have the ability to produce degrading enzymes such as lipases to catabolise the long-chain hydrocarbons such as waxes.

\section{References}

1. Arunkumar N, Banu JG, Gopalakrishnan N, Prakash AH. Isolation, screening and characterization of microbial surfactants producing wax degrading bacteria from cotton mealybugs, Phenacoccus solenopsis Tinsley and Ferrisia virgata Cockerell (Homoptera: Pseudococcidae). Journal of Entomology and Zoology Studies. 2017; 5(2):11911195.

2. Hira Shahjahan, Javed Khan, Ahmad-Ur-Rahman Saljoqi, Ehsan Ul Haq, Hussain Shah, Imtiaz Khan, et al. Biological parameters and feeding efficiency of Chrysoperla Carneastephens (Neuroptera: Chrysopidae) feed on Citrus mealy bug Planococcus Citri (Risso) (Hemiptera: Pseudococcidae) under controlled conditions. Int. $\mathrm{J}$ Agric. Extension Social Dev. 2020;3(1):46-51.

3. Meyerdirk DE, Warkentin R, Attavian B, Gersabeck E, Francis A, Adams M et al. Biological control of the pink hibiscus mealybug project manual. United States Department of Agriculture, Washington, DC, USA, 1998.

4. Mobaiyen H, Sedegbayan H, Dehnad A, Naseri A, Por FA, Shahla NM. Study on liquid paraffin decomposer microorganisms isolated from soils of Julfa-Iran. African Journal of Microbiology Research. 2013; 7(3):260-265.

5. Queiroga CL, Nascimento LR, Serra GE. Evaluation of paraffins biodegradation and biosurfactant production by Bacillus subtilis in the presence of crude oil. Brazilian Journal of Microbiology. 2003; 34:321-324.

6. Rocha C, San-Blas F, San-Blas G, Vierma L. Biosurfactant production by two isolates of Pseudomonas aeruginosa. World Journal of Microbiology and Biotechnology. 1992; 8:125-128.

7. Sambrook J, Fritsch EF, Maniatis T. Molecular cloning: A laboratory Manual, 2nd ed. Cold Spring Harbor Laboratory, New York, USA, 1989.

8. Sadeghazad A, Ghaemi N. Microbial prevention of wax precipitation in crude oil by biodegradation mechanism. Society of petroleum engineers. DOI: 10.2118/80529MS, 2003.

9. Skariyachan S, Megha M, Kini MN, Mukund KM, Rizvi A, Vasist K. Selection and screening of microbial consortia for efficient and ecofriendly degradation of plastic garbage collected from urban and rural areas of Bangalore. India Environmental Monitoring and Assessment. 2015; 187(1):1-14.

10. Singer MEV, Finnerty WR. Physiology of biosurfactant synthesis by Rhodococcus species. Canadian Journal of Microbiology. 1990; 36:741-745.

11. Sreerag RS, Jayaprakas CA, Ragesh L, Kumar SN. Endosymbiotic Bacteria Associated with the Mealy Bug, Rhizoecus amorphophalli (Hemiptera: Pseudococcidae). International Scholarly Research Notices, 2014.

12. Van Beilen JB, Panke S, Lucchini S, Franchini AG. Analysis of Pseudomonas putida alkane-degradation gene clusters and flanking insertion sequences: evolution and regulation of the alk genes. Microbiology. 2001; 147:1621-1630.

13. Yang J, Yang Y, Wu WM, Zhao J, Jiang L. Evidence of polyethene bidegradation by bacterial strains from the gut of plastic eating waxworms. Environmental Science and Technology. 2014; 48(23):13776-84.

14. Holt JG. Bergey's manual of determinative bacteriology, 9th edn, Williams \& Wilkins: Baltimore, USA, 1994, 1787. 